April 2013

\title{
Major incidents in Kenya: the case for emergency services development and training
}

Benjamin Wachira

Aga Khan University, benjamin.wachira@aku.edu

Wayne Smith

University of Cape Town

Follow this and additional works at: http://ecommons.aku.edu/eastafrica_fhs_mc_intern_med Part of the Emergency Medicine Commons

\section{Recommended Citation}

Wachira, B., Smith, W. (2013). Major incidents in Kenya: the case for emergency services development and training. Prehospital and Disaster Medicine, 28(2), 170-173.

Available at: http://ecommons.aku.edu/eastafrica_fhs_mc_intern_med/20 


\title{
Major Incidents in Kenya: The Case for Emergency Services Development and Training
}

\author{
Benjamin W. Wachira, MBChB, Dip PEC, MMed EM, FCEM; ${ }^{1}$ \\ Wayne Smith, MBChB, EMDM, ACEM ${ }^{2}$
}

1. Accident and Emergency Department, Aga Khan University Hospital - Nairobi, Nairobi, Kenya

2. Division of Emergency Medicine, University of Cape Town, Cape Town, South Africa

\author{
Correspondence: \\ Benjamin W. Wachira, MBChB, Dip \\ PEC, MMed EM, FCEM \\ Aga Khan University Hospital - Nairobi \\ Accident and Emergency Department \\ PO Box 30270 \\ Nairobi 00100, Kenya \\ E-mail: benjawambugu@hotmail.com
}

Conflicts of interest: The authors have no conflicts of interest to disclose.

Keywords: disasters; Emergency Medical Services; EMS; firefighters; emergency medicine

\begin{abstract}
Abbreviation:
EMS: Emergency Medical Services

KRCS: Kenya Red Cross Society
\end{abstract}

Received: June 9, 2012

Accepted: August 25, 2012

Revised: September 14, 2012

Online publication: February 6, 2013

doi:10.1017/S1049023X13000010

\begin{abstract}
:
Kenya's major incidents profile is dominated by droughts, floods, fires, terrorism, poisoning, collapsed buildings, accidents in the transport sector and disease/epidemics. With no integrated emergency services and a lack of resources, many incidents in Kenya escalate to such an extent that they become major incidents. Lack of specific training of emergency services personnel to respond to major incidents, poor coordination of major incident management activities, and a lack of standard operational procedures and emergency operation plans have all been shown to expose victims to increased morbidity and mortality.

This report provides a review of some of the major incidents in Kenya for the period 2000-2012, with the hope of highlighting the importance of developing an integrated and well-trained Ambulance and Fire and Rescue service appropriate for the local health care system.
\end{abstract}

Wachira B, Smith W. Major incidents in Kenya: the case for emergency services development and training. Prehosp Disaster Med. 2013;28(2):170-173.

\section{Introduction}

In health service terms, a major incident can be defined as any incident where the location, number, severity, or type of live casualties requires extraordinary resources. ${ }^{1}$ Since 2000, there have been 2,518 major incidents in 56 countries in Africa; 113 have been in Kenya. ${ }^{2}$ Kenya's major incidents profile is dominated by droughts, floods, fires, terrorism, collapsed buildings, accidents in the transport sector and disease/epidemics. With no integrated emergency services and a lack of resources, many incidents in Kenya escalate to such an extent that they become major incidents. ${ }^{3}$

The Republic of Kenya is located on the equator in eastern Africa, and borders Ethiopia, Somalia, Tanzania, Uganda and Sudan; the country's east coast is along the Indian Ocean. Kenya is divided into eight provinces as shown in Figure 1: Central, Coast, Eastern, North Eastern, Nyanza, Rift Valley and Western and Nairobi. The country has a population of over 38 million people; Nairobi, the capital, is the largest city of Kenya, with a population of more than three million people. ${ }^{4}$

The efficacy of emergency response to major incidents in Kenya varies greatly across the different services in the country. Due to inadequate Emergency Medical Services (EMS), many injured victims arrive in hospital by private means, eg, by car, truck, or taxi. $^{5}$ St. John Ambulance is the only public EMS provider in Kenya. ${ }^{6}$ It has only nine ambulances across the country, six of which are in Nairobi. Emergency Plus Medical Services (E-Plus) is a private company owned by the Kenya Red Cross Society (KRCS). ${ }^{7}$ It offers Emergency Medical Services including ambulance services. It has ten ambulances in Nairobi and 21 in other regions of the country. Though private, E-Plus has been involved in the response to major incidents across the country, in keeping with the disaster relief and humanitarian activities of the KRCS.

Where fire or chemical spillage is the predominant threat, a major incident response is required from the Fire Service. According to the Kenya National Fire Brigade Association, there are approximately 30 operational fire engines in the country, with another 34 out of commission (F. Liech, unpublished data, April 2012). There are 535 trained firefighters in 26 major towns across the country. Nairobi is served by one fire station situated close to a traffic-choked business district. It has three working fire engines and 146 firefighters who work in shifts. 


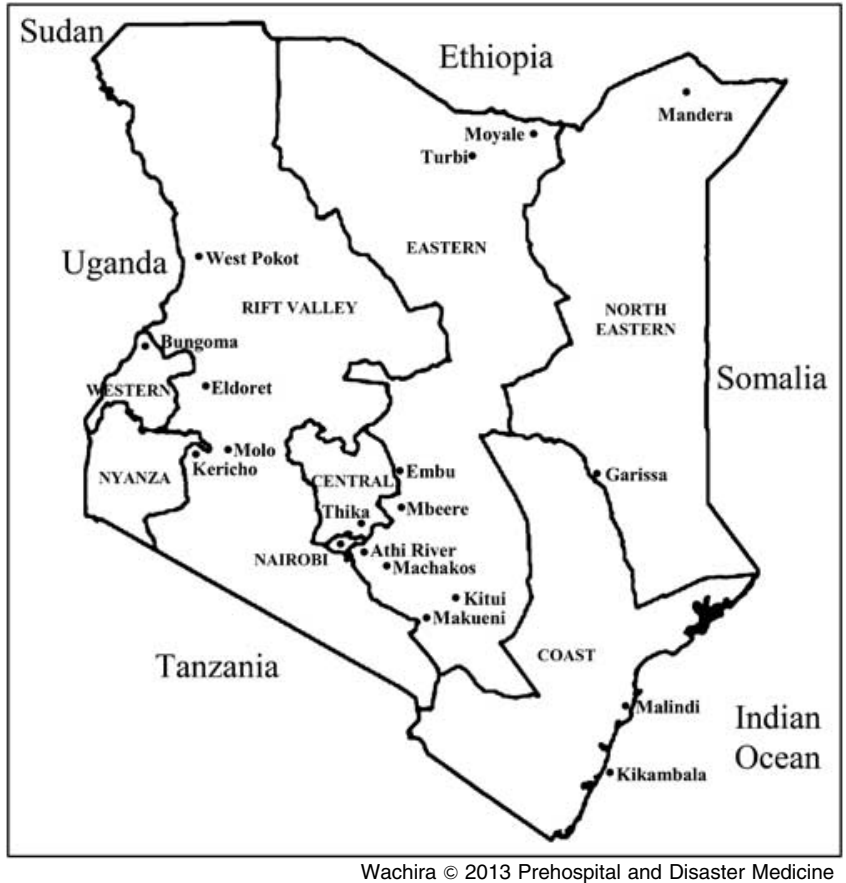

Figure 1. The Eight Provinces of Kenya

This report provides a review of some of the recent major incidents in Kenya, with the hope of informing the training and development of EMS and fire and rescue services appropriate for the local health care system.

\section{Classification of Major Incidents in Kenya}

The major incidents in Kenya can be broadly grouped into natural incidents and manmade incidents. Natural incidents include droughts, floods, landslides, volcanic eruptions, and epidemics. Over 1,500 people have died, and more than one million have been affected by natural major incidents in Kenya in the last 12 years. ${ }^{2}$ Manmade incidents include transport incidents, poisoning incidents, terrorist incidents, mass-gathering incidents and industrial incidents. The distribution of victims for some of the manmade incidents in the last 12 years is shown in Figure 2.

\section{Examples of Recent Major Incidents in Kenya Epidemics}

An outbreak of highland malaria in Kenya killed more than 300 people and infected over 158,000 others in June and July 2002. ${ }^{8}$ The epidemic affected the Rift Valley and Nyanza provinces in the west of the country, approximately $300 \mathrm{~km}$ north of Nairobi.

In Bungoma district in June 2004, 141 cases of Leptospirosis, a zoonotic disease, were confirmed in a high school; there were six fatalities. ${ }^{9}$ Additional cases and two fatalities were also confirmed at nearby primary school. In total, 12 people died and 859 were affected. ${ }^{3}$

On January 23, 2006, an increased number of suspected meningitis cases and deaths were reported in West Pokot district. $^{10}$ On March 13, 2006, 76 cases and 17 deaths were reported from this outbreak. An outbreak alert, case definitions, and guidelines on how to manage cases were sent to all the health facilities in the district. Some of the Kenyan patients were treated in Uganda, a neighboring country.

Eleven deaths were reported from Rift Valley fever in Garissa district in the North Eastern province on December 20, 2006. ${ }^{11}$

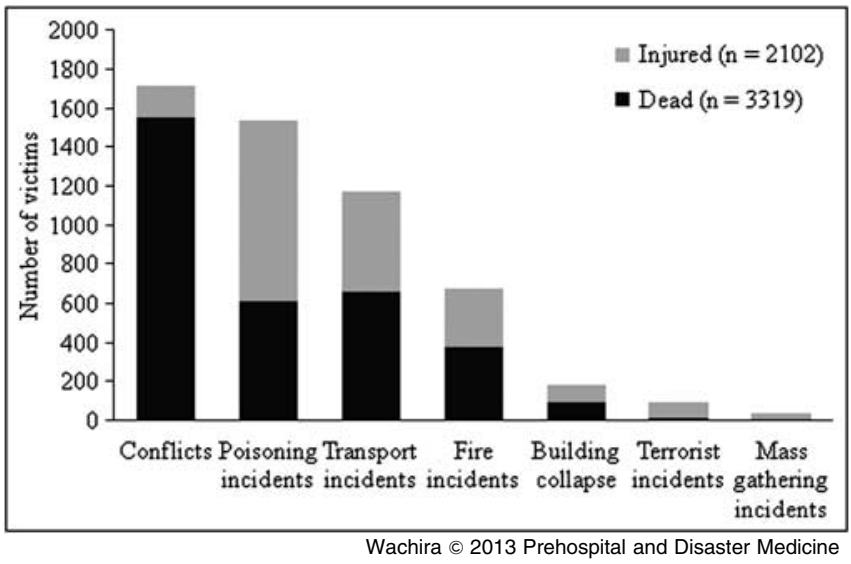

Figure 2. Distribution of Victims-Manmade Incidents, 2000-2012

The outbreak peaked on December 24th, with more than 300 people hospitalized across the country.

In 2008, cholera outbreaks were reported in Nyanza, North Eastern, Western and Rift Valley provinces. ${ }^{12}$ Nyanza was the most affected province, with 771 cases and 53 deaths being reported from 10 districts as of March 31st. In Mandera East district, 325 cases and 11 deaths were reported from January 16th through March 14th. Nationwide, there were 1243 cases and 122 deaths from November 27, 2007 through April 10, 2008. The following year, 11,769 cholera cases were reported, including 274 deaths. ${ }^{12}$ This was the highest number of cases in the country in 10 years. The peaks occurred during March-April, June and October-November.

\section{Conflicts}

At the end of December 2007, widespread violence broke out across the country following the announcement of the results of presidential elections held on December 27th. ${ }^{13}$ These were systematic attacks based on ethnicity and political leanings. Attackers organized along ethnic lines, assembled considerable logistical means, and travelled long distances to burn houses, maim, kill and sexually assault their occupants because they were of particular ethnic groups and political persuasion. Guilty by association was the guiding force behind deadly "revenge" attacks, with victims being identified not for what they did, but for their ethnic association with other perpetrators. More than 1,300 people were killed, and scores more injured at the hands of mobs, militia and state security agents including the police and paramilitary units. ${ }^{14}$ By February 28, 2008, more than 350,000 Kenyans were classified as Internally Displaced Persons, living in refugee camps. The largest single loss of life was from a church fire outside Eldoret in the Rift Valley. The church was providing shelter from the violence to more than 200 people, and was set alight by rioters, burning 35 people to death.

Traditionally, cattle rustling took place on a seasonal basis and was mainly associated with rites of passage into adulthood. ${ }^{15}$ After circumcision, the newly-initiated men took part in cattle raids to demonstrate their prowess and valor. The raiders were mainly focused on cattle; sometimes women were taken as wives. The raided communities would in turn organize counter-raids to recover the stolen livestock. Such raids did not fundamentally disrupt the lives and livelihoods of the communities affected, since they were not as frequent or fatal as the current ones. Modernity has brought with it a more deadly form of cattle rustling. Raids are well planned 
and executed with military precision, characterized by the use of modern and destructive weapons such as MK4s, G3s, AK47s, HK11s, grenades, and mortars. This has virtually transformed cattle rustling from a traditional practice to a highly organized crime. The primary element in these raids is that the cattle stolen are taken to urban centers where they are slaughtered and sold as beef.

On September 15, 2009, more than 400 raiders stormed Kinampiu village in Laikipia North district (in central Kenya bordering northern districts), and killed 21 villagers, among them eight children and three women, during an attempt to steal 10,000 cattle. ${ }^{16}$ Forty cattle, 20 goats and 30 sheep were stolen, and another 26 shot dead. The villagers retaliated, with the help of Kenya Police Reservists, and killed eight raiders. The Kenya police provided backup and three additional raiders were killed, bringing the total number of raiders killed to 11 .

Moyale district, in Kenya's northern border with Ethiopia, has been the scene of recent tribal clashes involving mainly Borana and Gabra communities. ${ }^{17}$ These communities often experience tension over the use, access, and control of resources, mainly pasture and water. In the past, tensions have ranged from small, sporadic skirmishes to large-scale clashes, as witnessed in the Turbi massacre of July 12, 2006, in which 60 were killed, including 26 children. ${ }^{17}$ A rapid assessment conducted by the Kenya Red Cross Society found that fighting in January 2012 resulted in approximately 60 deaths, 57 injured, and 1,000 houses, health facilities, water points and schools vandalized or burned, with some 5,000 families displaced and without access to shelter or basic services. ${ }^{17}$

\section{Poisoning Incidents}

Nearly 100 people died and 512 were hospitalized, some suffering from blindness, on November 17, 2000, after drinking a contaminated, illegal brew in Nairobi. ${ }^{18}$ This batch of brew was suspected to have been laced with methanol.

In June 2005, a total of 192 cases of poisoning were identified in the eastern district of Machakos, with 56 deaths involving consumption of an illicit brew. ${ }^{19}$ Twelve people were blinded. The high mortality was due to the high methanol concentrations in the illicit brew (over $90 \mathrm{mg} / 100 \mathrm{ml}$ ), delay in seeking medical care, and less than optimum intensive care.

The outbreak of acute aflatoxicosis in Makueni, Machakos, Kitui, Embu, Mbeere and Thika districts was one of the most severe episodes of human aflatoxin poisoning in history. ${ }^{20}$ As of July 20, 2004, a total of 317 cases had been reported, with 125 deaths. A limited number of new cases continued to be detected after that date. This incident resulted from ingestion of locally-grown maize which had been contaminated with aflatoxin during storage under damp conditions.

\section{Transport Incidents}

Two buses collided at Kapkantugor, near Kericho, on March 29, 2000 , and burst into flames on impact. ${ }^{21}$ Seventy-four people died, including seven children; 58 people who sustained various injuries were treated in hospitals in the area.

On April 1, 2001, two buses collided on a bridge over the Sabaki River near the coastal town of Malindi, and plunged 200 feet into the flooded, crocodile-infested river. ${ }^{22}$ On the day of the accident, 14 bodies were recovered and 28 people taken to hospital. Due to inadequate equipment and the river's strong current, it would be two days before one of the buses was plucked from the swirling water after numerous failed attempts. Twenty additional bodies were recovered, but more remained missing.

\section{Fire Incidents}

On August 20, 2000, nine runaway rail tank cars, six carrying liquefied gas, rolled down the slope from Marimbet railway substation towards Athi River and collided with another train at the station, bursting into flames. ${ }^{3}$ There were approximately 30 houses around the station, a number of which were reduced to charred rubble. Twenty-five people were burned to death and at least 36 were injured, some with severe burns.

At $1.40 \mathrm{Am}$ on March 26, 2001, fire swept through a dormitory of the Kyanguli Secondary school in Machakos, killing at least 59 teenage boys. ${ }^{23}$ As many as 28 students were admitted to hospital, some in critical condition, with burns covering 60 percent of their bodies. The fire brigade did not arrive.

On January 28, 2009, a supermarket in downtown Nairobi caught fire. ${ }^{24}$ Fire engines from the Nairobi City Council, Kenya Air Force, Kenya Airports Authority and private firms all ran out of water. Fire hydrants in the Kenyan capital had fallen into disuse, and fire trucks had to navigate along streets clogged with traffic to get water three $\mathrm{km}$ away from the incident. Twentynine people died; two people survived. There is no data regarding the number of people injured.

Three days later, on January 31, 2009, hundreds of people gathered near Molo to collect spilled fuel from an overturned petrol tanker when it burst into flames. ${ }^{24}$ Overwhelmed area hospitals were packed with victims, including small children, suffering from horrific burns. Some were loaded onto ambulances for transfer to specialist burns units. Supplies, including body bags and extra medicine, were sent by helicopter to the region. Three hundred seventy-three people were affected; 130 were badly burned, some beyond recognition, and a further 72 died in hospitals. One hundred seventy-one were treated in various hospitals for their injuries and discharged.

A fire swept through Sinai slum in Nairobi's Industrial Area on September 12, 2011..$^{25}$ Most of the victims were scooping petrol from a trench that carries dirty water from a Kenya Pipeline Company depot. In total, 82 bodies were recovered and more than 100 people injured. The rescue efforts were hampered by the poor access roads to the slums and by disorganized rescue efforts, as there was no command center. More than eight hours after the blast occurred, bodies were still lying uncovered in the slimy mud.

\section{Building Collapse}

Ronald Ngala Street on the edge of Nairobi's business district is usually busy, and was even more so during the lunch break when a five-story building still under construction collapsed on January $23,2006 .{ }^{26}$ Among those crushed in the tangled mess of concrete and steel were construction workers and women who had been selling food to the workmen on the ground floor. Rescue workers immediately began operations to rescue an unknown number of people trapped in the rubble; however, a lack of collapsed structure rescue equipment and emergency supplies reportedly hampered the relief effort, and international assistance was requested. The US Marines deployed from Diibouti, and specialist Israeli teams joined the rescue effort. ${ }^{27}$ At least 20 people were killed and 92 seriously injured.

\section{Terrorist Incidents}

On November 28, 2002, a vehicle crashed through a barrier outside a hotel and into the lobby in Kikambala. ${ }^{28}$ Once inside, the car bomb detonated, killing 18 people including the three suicide bombers. More than 80 people were injured. 


\section{Mass-Gathering Incidents}

At least seven people were killed and 30 injured after a crowd tried to get into the Nyayo National stadium on October 23, 2010 during a match in the capital Nairobi between AFC Leopards and Gor Mahia, two of the country's top teams. ${ }^{29}$ Fourteen of the wounded were in critical condition.

\section{Discussion}

This paper identifies the epidemiology and incidence of some of Kenya's major incidents for the period 2000-2012. At least four major incidents have occurred in Kenya each year in the last 12 years. ${ }^{2}$ The repetitive nature of both the natural and manmade incidents recently, with a high number of deaths and injuries, suggests that Kenya is still not adequately prepared to handle major incidents.

Similarly, major incidents in sub-Saharan Africa have increased in frequency, severity and impact. On average, almost two major incidents of significant proportions have been recorded every week in the region since $2000 .^{2}$ Lack of specific training of emergency services personnel to respond to major incidents has been shown to expose victims to greater risks and slow recovery. Poor coordination of major incident management activities has been attributed to lack of resources, standard operational procedures, and emergency operation plans. This situation has led to duplication of efforts and wasteful use of resources.

\section{References}

1. Hodgetts TJ, Mackway-Jones K. (eds). Major Incident Medical Management and Support, 2nd ed. London: BMJ Books; 2002:3.

2. The OFDA/CRED International Disaster Database - Brussels. WHO Collaborating Centre for Research on the Epidemiology of Disasters (CRED) Web site. http://www. emdat.be. Accessed May 22, 2012.

3. Ministry of State for Special Programmes, Office of the President. National policy for disaster management in Kenya. Nairobi: Government of Kenya, 2009.

4. Kenya National Bureau of Statistics (KNBS). Population and Housing Census. http:// www.knbs.or.ke/censuspopulation.php. Published 2011. Accessed May 28, 2012.

5. Saidi HS. Initial injury care in Nairobi, Kenya: a call for trauma care regionalization. East Afr Med J. 2003;80:480-483.

6. St John Association of Kenya. The Order of St. John Web site. http://www. orderofstjohn.org/kenya. Accessed May 22, 2012.

7. About us. Emergency Plus medical services Web site. http://www.eplus.co.ke/index. php?option $=$ com_content $\&$ view $=$ article $\& i d=46 \& I t e m i d=27$. Accessed May 22, 2012.

8. KENYA: Nearly 300 killed in malaria epidemic. Medilinks Web site. http:// medilinkz.org/east-africa/kenya/557.html. Accessed May 22, 2012.

9. Leptospirosis in Kenya. World Health Organization (WHO) Web site. http:// www.who.int/csr/don/2004_06_17a/en/. Accessed May 28, 2012.

10. Ministry of Health: Meningococcal Meningitis Outbreak Report - West Pokot District-Rift Valley province March-April 2006. http://www.who.int/hac/crises/ken/ sitreps/Kenya_West_Pokot_district_report_March_April_2006.pdf. Published 2006. Accessed May 28, 2012.

11. Centers for Disease Control and Prevention. Rift Valley Fever Outbreak - Kenya. November 2006 - January 2007. MMWR CDC Surveill Summ. 2007;56:73-76.

12. World Health Organization (WHO). Cholera Country Profile: Kenya. http:// www.who.int/cholera/countries/KenyaCountryProfile2010.pdf. Accessed May 28, 2012.

13. Commission of Inquiry into Post-Election Violence: Report of the Commission of Inquiry into Post-Election Violence (CIPEV). http://www.dialoguekenya.org/Commission $\% 20$ reports/October-15th-2008\%20-\%20Report\%20of\%20the\%20Commission\%20of \%20Inquiry\%20into\%20Post-Election\%20Violence\%20(CIPEV).pdf. Published 2008. Accessed September 14, 2012.

14. Full Kenyan post election violence report 2008. WikiLeaks Web site. http:// wikileaks.org/wiki/Full_Kenyan_post_election_violence_report_2008. Accessed May 28, 2012.

15. National Council of Churches of Kenya: Memorandum on Cattle Rustling. http:// www.ncck.org/index.php?option $=$ com_content $\&$ view $=$ article\&id $=112 \& I t e m i d=62$. Published 2009. Accessed May 28, 2012.
Preparedness to take action when major incidents occur is the prime instrument for reducing impacts. A structured multidisciplinary response to major incidents is of critical importance. Development of an integrated national emergency services response system in Kenya should be a multi-stakeholder process, involving local authorities and private partners. With management of everyone's interests and roles, and agreement on the Command and Control structures, preparedness capacity can be built and streamlined, improving coordination during major incidents. Evidence from recurrent major incidents in the country should inform the training of all EMS and Fire and Rescue services and the development of a well-connected, reliable central dispatch system. Key coordination hubs and standard operating procedures should also be established and tested with comprehensive drills, so that institutions and communities can be more prepared to act in major incidents.

\section{Conclusion}

This report highlights the increasing frequency, severity and impact of major incidents in Kenya. Emergency services still remain largely underdeveloped and ill prepared. This has led to increased morbidity and mortality of victims of major incidents in the country. Training and development of EMS and Fire services in Kenya based on recent major incidents, along with the development of integrated Command and Control structures, will greatly enhance the country's preparedness and response to major incidents.

16. United Nations Office for the Coordination of Humanitarian Affairs (OCHA). KENYA. 32 die in cattle raids. http://www.google.com/url?sa $=t \& r c t=j \& q=\&$ esrc $=$ $\mathrm{s} \&$ source $=$ web $\& \mathrm{~cd}=3 \& \mathrm{cad}=$ rja\&ved $=0 \mathrm{CEIQFjAC} \& u r l=\mathrm{http} \% 3 \mathrm{~A} \% 2 \mathrm{~F} \% 2 \mathrm{Focha}$ online.un.org\%2FOchaLinkClick.aspx\%3Flink\%3Docha\%26docId\%3D1119519\&ei= WPRSUI71BIWH0AWHkoCoBQ\&usg=AFQjCNGL6Og6jYs-fz-kaYkb-5_Si7veQ \&sig2=adqwQykWzIzMlueai9e_JA. Published 2009. Accessed September 14, 2012.

17. The International Federation of Red Cross and Red Crescent Societies (IFRC): Disaster relief emergency fund (DREF). Kenya: Civil Unrest - Moyale. http://www. ifrc.org/docs/Appeals/12/MDRKE021.pdf. Accessed May 22, 2012.

18. Kenya's 'shameful national disaster'. BBC Web site. http://news.bbc.co.uk/2/hi/ africa/1032331.stm. Accessed May 22, 2012.

19. Centers for Disease Control and Prevention. Division of Epidemiology and Surveillance Capacity Development - Annual Report 2005. http://www.cdc.gov/ globalhealth/fetp/pdf/2005AnnualReportDESCD0207.pdf. Published 2006. Accessed May 22, 2012.

20. Centers for Disease Control and Prevention. Outbreak of Aflatoxin Poisoning Eastern and Central Provinces, Kenya, January - July 2004. http://www.cdc.gov/ $\mathrm{mmwr} /$ preview/mmwrhtml/mm5334a4.htm. Published 2004. Accessed May 22, 2012.

21. Kenyan bus crash: 74 confirmed dead. BBC Web site. http://news.bbc.co.uk/2/hi/ africa/696017.stm. Accessed May 22, 2012.

22. Kenyan crash bus pulled from river. CNN Web site. http://archives.cnn.com/2001/ WORLD/africa/04/04/kenya.bus/index.html. Accessed May 28, 2012.

23. Rowan D. Kenya: School fire kills at least 59 students.World Socialist Web site. http:// www.wsws.org/articles/2001/mar2001/keny-m30.shtml. Accessed May 28, 2012.

24. Ministry of State for Special Programmes. Disaster Management and National Policy. http://www.sprogrammes.go.ke/index.php?option $=$ com_content\&task=view\& id=257\&Itemid=141. Accessed May 28, 2012.

25. Oneri W, Mutiga M. Disaster offered a snapshot of all you need to know about slum life. Daily Nation Web site. http://www.nation.co.ke/News/-/1056/1235364/-/ $10 \mathrm{fwjyfz/-/}$. Accessed May 28, 2012.

26. Allen K. Kenya rescue mission gathers pace. BBC Web site. http://news.bbc.co.uk/2/ hi/africa/4643216.stm. Accessed May 28, 2012.

27. More tapped Kenyans pulled out. BBC Web site. http://news.bbc.co.uk/2/hi/africa/ 4642182.stm. Accessed May 22, 2012.

28. Kenya terror strikes target Israelis. BBC Web site. http://news.bbc.co.uk/2/hi/africa/ 2522207.stm. Accessed May 22, 2012.

29. Seven killed in Kenya soccer stampede. Reuters Web site. http://www.reuters. com/article/2010/10/23/us-kenya-football-stampede-idUSTRE69M1XP20101023. Accessed May 28, 2012. 